\title{
Soluble Antigen Arrays for Selective Desensitization of Insulin- Reactive B Cells
}

\author{
Martin A. Leon ${ }^{\dagger, 1}$, Scott M. Wemlinger ${ }^{\dagger, 2}$, Nicholas R. Larson ${ }^{3}$, Justin K. Ruffalo ${ }^{4}$, C. \\ Russell Middaugh ${ }^{3}$, John C. Cambier ${ }^{2}$, Cory Berkland ${ }^{*}, 1,3,4$ \\ ${ }^{1}$ Department of Chemistry, University of Kansas 1251 Wescoe Hall Drive, Lawrence, KS 66045, \\ USA \\ 2Department Immunology \& Microbiology, University of Colorado Denver AMC, 12800 E. 19th \\ Ave., Aurora, CO 80045 \\ ${ }^{3}$ Department of Pharmaceutical Chemistry, University of Kansas 2095 Constant Avenue, \\ Lawrence, KS 66047, USA \\ ${ }^{4}$ Department of Chemical and Petroleum Engineering, University of Kansas 1530 West $15^{\text {th }}$ \\ Street, Lawrence, KS 66045, USA
}

\section{Abstract}

\begin{abstract}
Autoimmune diseases are believed to be highly dependent on loss of immune tolerance to selfantigens. Currently, no treatments have been successful clinically in inducing autoantigen-specific tolerance, including efforts to utilize antigen-specific immunotherapy (ASIT) to selectively correct the aberrant autoimmunity. Soluble antigen arrays (SAgAs) represent a novel autoantigen delivery system composed of a linear polymer, hyaluronic acid (HA), displaying multiple copies of conjugated autoantigen. We have previously reported that Soluble Antigen Arrays proteolipid protein (SAgAPLP) induced tolerance to a specific multiple sclerosis (MS) autoantigen, proteolipid peptide (PLP). Utilizing SAgA technology, we have developed a new ASIT as a possible type 1 diabetes (T1D) therapeutic by conjugating human insulin to HA, known as Soluble Antigen Array Insulin $\left(\mathrm{SAgA}_{\text {Ins }}\right)$. Three types were synthesized: low valency ${ }_{1 v} \mathrm{SAgA}_{\text {Ins }}(2$ insulins per $\mathrm{HA})$, medium valency ${ }_{m v} \mathrm{SAgA}_{\text {Ins }}$ (4 insulins per $\mathrm{HA}$ ) and, high valency ${ }_{\mathrm{hv}} \mathrm{SAgA}_{\text {Ins }}(9$ insulins per HA) to determine if valency differentially modulates the ex vivo activity of insulin-binding $\mathrm{B}$ cells (IBCs). Extensive biophysical characterization was performed for the SAgA molecules. SAgA Ins molecules were successfully used to affect the biologic activity of IBCs by inducing desensitization of the $\mathrm{B}$ cell antigen receptors (BCR). $\mathrm{SAgA}$ Ins bound specifically to insulin-
\end{abstract}

\footnotetext{
*To whom correspondence should be addressed: University of Kansas, 2030 Becker Drive, Lawrence, KS 66047., Phone: (785) 864-1455, Fax: (785) 864-1454, berkland@ku.edu.

Co-first authors.

AUTHOR CONTRIBUTIONS

M.A.L. performed the synthesis, characterization, and biophysical analysis for the novel soluble antigen arrays and wrote the manuscript. S.M.W. performed the ex vivo cell assays, flow cytometry, data analysis, and wrote the manuscript. J.K.R. helped with synthesis and biophysical data analysis. N.L. and C.R.M. performed and interpreted data from biophysical analyses. J.C.C. and C.J.B. are the principal investigators. Finally, support for the NMR instrumentation was provided by NIH Shared Instrumentation Grant \# S10RR024664 and NSF Major Research Instrumentation Award \# 1625923

Supporting Information.

LC-MS data confirming Ins-Alk was synthesized and RP-HPLC chromatograms for conjugation efficiency for mvSAgA Ins and hvSAgAIns.
} 
reactive $\mathrm{B}$ cells without blocking epitopes recognized by antibodies against the Fc regions of membrane immunoglobulin or CD79 transducer components of the BCR. Pre-incubation of IBCs (125Tg) with $\mathrm{SAgA}_{\mathrm{Ins}}$, but not HA alone, rendered the IBCs refractory to re-stimulation. SAgA Ins induced a decrease in BCR expression and IP3R-mediated intracellular calcium release.

Surprisingly, $\mathrm{SAgA}_{\text {Ins }}$ binding to BCR on the surface of IBCs induced the observed effects at both high and low $\mathrm{SAgA}_{\text {Ins }}$ valency. Future studies aim to test the effects of $\mathrm{SAgA}$ Ins on disease progression in the VH125.NOD mouse model of T1D.

\section{Keywords}

Autoimmune diseases; type 1 diabetes; Soluble Antigen Array; Insulin; B cell antigen receptors; tolerance; ex vivo; epitope; valency; anergized

\section{INTRODUCTION}

Autoimmune diseases, such as multiple sclerosis (MS), ${ }^{1,2}$ type 1 diabetes (T1D), ${ }^{3-7}$ neuromyelitis optica, ${ }^{8,9}$ and lupus erythematosus, ${ }^{10,11}$ involve loss of tolerance to selfantigens in autoreactive B cells, leading to tissue damage, disability, and death. In individuals afflicted by T1D, the insulin-producing beta cells in the pancreas are targeted by an autoimmune response, resulting in cell death. ${ }^{3}$ While production of autoantibodies is a strong predictor of the development of T1D, no studies have shown such antibodies to be pathogenic. Instead, studies have suggested B cells may contribute to the development of disease via their antigen presenting function and/or cytokine production. ${ }^{3-7}$ Rituximab works by depleting $\mathrm{B}$ cells and has been used to treat certain autoimmune disease, including T1D. However, this monoclonal anti-CD20 antibody causes global B cell depletion, increasing risk of infection, and can exhibit limited efficacy. ${ }^{12-14}$ Antigen-specific immune therapy (ASIT) has emerged as a potential means to selectively induce immune tolerance, 15,16 via an intervention similar to allergy shot therapies, which often use soluble antigens to restore tolerance towards specific allergens. ${ }^{17}$ Since B cells specificity is determined by cell surface antigen receptors, antigen-specific strategies to selectively tolerize or delete autoreactive B cells offer a promising approach to ASIT.

In now classic studies, Dintzis and co-workers analyzed the delivery of antigens bound to polymers, and reported two different antigen-specific responses dictated by the following properties: polymer molecular weight, solubility, and antigen valency and spacing. An immunogenic response was seen when polymers delivering haptens were large ( $>100 \mathrm{kDa})$, rigid, and poorly soluble. A tolerogenic effect occurred when polymers delivering haptens were smaller $(<100 \mathrm{kDa})$, flexible, soluble, and often with relatively lower hapten density. ${ }^{18-21}$ Interestingly, the molecular properties that encourage immune tolerance are also favorable for accessing B cell compartments in secondary lymphoid organs $(<100 \mathrm{kDa})^{22,23}$ and may promote selectivity to antigen-specific $\mathrm{B}$ cells over other professional antigen presenting cells (pAPCs). We hypothesized that an antigen delivery system exhibiting molecular properties capable of inducing tolerance by engaging antigen-specific B cells may be a viable therapeutic for T1D. 
Our group has previously described a novel antigen delivery system known as Soluble Antigen Arrays (SAgAs), which were originally designed based on 'Dintzis rules'. SAgAs are constructed using a hydrophilic linear polymer hyaluronic acid (HA) grafted with multiple repeating autoantigen. SAgA prototypes used proteolipid protein peptide (PLP $\left.{ }_{139-151}\right)$ to treat experimental autoimmune encephalomyelitis induced by this same peptide. ${ }^{24-32}$ SAgA $A_{P L P}$ suppressed disease progression in many studies of this murine model used to mimic MS in humans. Our studies indicated SAgA engagement of B cell antigen receptors (BCRs) induced anergy, a known mechanism of peripheral immune tolerance. cSAgA $A_{P L P}$ constructed via a non-hydrolyzable linker chemistry (i.e. covalent) rather than a hydrolyzable linker ( $\mathrm{SAg} \mathrm{A}_{\mathrm{PLP}}$ ) showed greater binding in vitro to $\mathrm{B}$ cells and greater disease suppression in vivo. ${ }^{31,} 32$ In sum, SAgAs were able to target antigen-specific B cells, crosslink surface BCRs, and sustain receptor occupancy to effectively suppress autoreactive B cells.

We hypothesized that SAgAs composed of multiple human insulin molecules conjugated to HA may silence or delete B cells obtained from non-obese diabetic (NOD) mice transgenic for anti-insulin immunoglobulin heavy chain (VH125.NOD). Human insulin was conjugated onto HA using Copper-catalyzed Azide-Alkyne Cycloaddition (CuAAC) linker chemistry. Soluble Antigen Array Insulin ( $\mathrm{SAgA}_{\text {Ins }}$ ) products with different valency were synthesized (Scheme 1) and their biophysical properties were studied. Activity of $\mathrm{SAgA}_{\text {Ins }}$ was determined in B cells from both 125Tg (NOD) and VH125.NOD mice to confirm their ability to ligate BCR on the surface of insulin-specific B cells (IBCs). To further validate specificity, B cells (CD43-) purified from spleens of VH125.NOD mice and MD4 B cells (hen egg lysozyme (HEL) reactive) were mixed at approximately the same frequency as IBCs, thereby defining the ability of $\mathrm{SAgA}_{\text {Ins }}$ to selectively block binding of insulin to IBCs but not HEL binding to MD4 B cells. Lastly, to determine if $\mathrm{SAgA}_{\text {Ins }}$ can induce immune markers of anergy in IBCs, B cells from 125Tg mice were cultured in vitro with or without $\mathrm{SAgA}_{\text {Ins }}$, or HA alone. These cells where subsequently assayed for surface levels of BCR as well as other markers to determine cell stimulation or anergy.

\section{Experimental}

Materials-Cell Prime ${ }^{\mathrm{TM}} \mathrm{r}$-insulin recombinant human insulin was purchased from EMD Millipore Corporation (Chicago, IL). $N$-(3-dimethylaminopropyl)- $N$ '-ethylcarbodiimide hydrochloride (EDC), 2-( $N$-morpholino)ethane-sulfonic acid sodium salt (MES), tris(3hydroxypropyltriazolylmethyl)amine, sodium ascorbate (NaAsc), and Propargyl- $\mathrm{N}$ hydroxysuccinimidyl ester were purchased from Sigma-Aldrich (St. Louis, MO) and used as received without further purification. Hyaluronic acid (HA) sodium salt (MW $16 \mathrm{kDa}$ ) was purchased from Lifecore Biomedical (Chaska, MN). 11-azido-3,6,9-trioxaundecan-1-amine $\left(\mathrm{NH}_{2}-\mathrm{PEG}_{3}-\mathrm{N}_{3}\right), N$-hydroxysuccinimide, Copper (II) sulfate pentahydrate $\left(\mathrm{CuSO}_{4} \cdot 5 \mathrm{H}_{2} \mathrm{O}\right)$ was purchased from Acros Organics (Geel, Belgium). Alkyne-functionalized peptide bearing an $N$-terminal 4-pentynoic acid (homopropargyl, hp) modification, hpPLP $_{139-151}$ (hpHSLGKWLGHPDKF-OH) was originally synthesized in our laboratory via solid phase

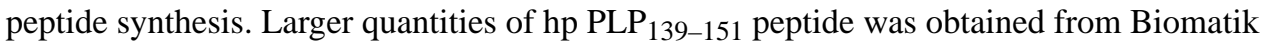
USA, LLC (Wilmington, DE). VH125.NOD and MD4 mice were purchased from The Jackson Laboratory and $125 \mathrm{Tg}$ mice were a kind gift from the laboratory of Dr. Rachel 
Friedman (National Jewish Health, Department of Biomedical Research). CD43 negative selections were purchased from Miltenyi Biotec and Millipore Sigma respectively. B76 and HM79 were produced in the Cambier laboratory and were directly conjugated to fluorochromes (Thermo Fisher Scientific). 5 uM Indo-1 acetoxymethyl calcium indicator were purchased from Molecular Probes. All other chemicals and reagents were analytical grade and used as received.

Synthesis and Labeling of Soluble Antigen Arrays-Soluble antigen arrays (SAgAs were synthesized and characterized as previously reported. ${ }^{31,32}$ Protein conjugation was determined through gradient reverse-phase analytical high-performance liquid chromatography (RP-HPLC).

Synthesis of Alkyne-Functionalized Human Insulin (Ins-Alk)-Synthesis of Insalk was adapted from Patent No.: US 8,906,850 B2. $120.00 \mathrm{mg}$ of powdered human insulin is dissolved in $3000 \mu \mathrm{L}$ of anhydrous DMSO at room temperature followed by the addition of $120 \mu \mathrm{L}$ of triethylamine (TEA). The solution is stirred for $30 \mathrm{~min}$ at room temperature. Next, 1.2 equivalents of Propargyl-N-hydroxysuccinimidyl ester is slowly added to the insulin-TEA solution as a $1.0 \mathrm{M}$ solution of the Propargyl-N-hydroxysuccinimidyl ester in THF. The reaction is mixed for $1 \mathrm{~h}$ and then quenched via the addition of $9.7 \mu \mathrm{L}$ of a stock solution containing $250 \mu \mathrm{L}$ of ethanolamine in 5,000 $\mu$ of DMSO followed by mixing for five min. (37.8 mg, 30.51\%); LCMS (TOF ESI+) expected [M] $]^{+}: 5918.66$, found: 5918.66.

Synthesis of Azide Functionalized Hyaluronic Acid (HA-N $\mathbf{N}_{3}$ )-Synthesis of HA- $\mathrm{N}_{3}$ was adapted from $\mathrm{Hu}$ et al and Di Meo et al. Sodium hyaluronate $(93.9 \mu \mathrm{mol}, 16 \mathrm{kDa}$ average MW) was added to a $250 \mathrm{~mL}$ round bottom flask with stir bar, followed by $100 \mathrm{~mL}$ of $50 \mathrm{mM}$ 2-(N-morpholino)ethanesulfonic acid (MES) buffer $(\mathrm{pH}=4.0)$. The mixture was stirred until in solution ( $15 \mathrm{~min})$ before EDC $(23.1 \mathrm{mmol})$ was added neat, then $N$ hydroxysuccinimide $(18.8 \mathrm{mmol})$ was added neat. The mixture was stirred for $5 \mathrm{~min}$ before $\mathrm{H}_{2} \mathrm{~N}-\mathrm{PEG}_{3}-\mathrm{N}_{3}(4.51 \mathrm{mmol})$ in $20 \mathrm{~mL}$ MES buffer was added. The solution was then stirred for $24 \mathrm{~h}$ at room temperature before being dialyzed in 6-8 $\mathrm{kDa}$ cutoff dialysis tubing against $4.5 \mathrm{~L}$ of $1.0 \mathrm{M} \mathrm{NaCl}$ solution for $24 \mathrm{~h}$, then $4.5 \mathrm{~L}$ of deionized water $(4 \times 12$ hours). The volume in the bag was then transferred to vials, frozen, and lyophilized to yield a white powder $(1.61 \mathrm{~g}, 95.0 \%)$.

Synthesis of SAgA Insulin (SAgA $\left.\mathbf{A n s}_{\text {Ins }}\right)$-Three different reactions with 5 equivalents of Ins-Alk relative to $\mathrm{HA}-\mathrm{N}_{3}$ (to make ${ }_{1 v} \mathrm{SAgA}_{\text {Ins }}$ and ${ }_{\mathrm{mv}} \mathrm{SAgA}_{\text {Ins }}$ ) and 10 equivalents of InsAlk relative to HA- $\mathrm{N}_{3}\left({ }_{\mathrm{hv}} \mathrm{SAgA}\right.$ Ins $)$ were set up with the following conditions. HA- $\mathrm{N}_{3}(0.81$ $\mu \mathrm{mol})$ was added as a $15 \mu \mathrm{M}$ solution in phosphate buffer $(50 \mathrm{mM}, \mathrm{pH}=7.0)$ to a $100 \mathrm{~mL}$ round bottom flask with stir bar. Followed by the addition of insulin-alkyne, a $4.0 \mathrm{mM}$ or 8.1 $\mathrm{mM}$ solution in DMF (5 and 10 equivalents relative to $\mathrm{HA}-\mathrm{N}_{3}$ respectively) was also added. Then a premixed solution of THPTA $(60 \mu \mathrm{mol})$ and $\mathrm{CuSO}_{4} \cdot 5 \mathrm{H}_{2} \mathrm{O}(12 \mu \mathrm{mol})$ in phosphate buffer $(50 \mathrm{mM}, \mathrm{pH}=7.0)$ was added to the alkyne/azide mixture. Then a $100 \mu \mathrm{L}$ aliquot was removed for HPLC analysis. NaAsc $(242 \mu \mathrm{mol})$ was then added to the reaction mixture as a $100 \mathrm{mM}$ solution in phosphate buffer $(\mathrm{pH}=7.0)$. One reaction with 5 equivalence of Ins-Alk relative to $\mathrm{HA}-\mathrm{N}_{3}$ was stirred at room temperature for $24 \mathrm{~h}$ until some alkyne component was 
consumed to furnish ${ }_{1 v} \mathrm{SAgA}_{\text {Ins }}$. While two other reactions were stirred at elevated temperature $\left(40^{\circ} \mathrm{C}\right)$ for $24 \mathrm{~h}$ until all alkyne component was consumed to produce both ${ }_{\mathrm{mv}} \mathrm{SAgA} \mathrm{A}_{\text {Ins }}$ and ${ }_{\mathrm{hv}} \mathrm{SAgA}_{\text {Ins }}$. Additional $100 \mu \mathrm{L}$ aliquots were removed throughout the course of the reaction to determine the extent of conjugation. Upon completion of the reaction, the solution was quenched by adding $0.5 \mathrm{~mL}$ of $50 \mathrm{mM}$ EDTA, then transferred to $6-8 \mathrm{kDa}$ dialysis tubing and dialyzed against $4.5 \mathrm{~L}$ of $1.0 \mathrm{M} \mathrm{NaCl}(3 \times 8$ hours $)$, then $4.5 \mathrm{~L}$ of deionized $\mathrm{H}_{2} \mathrm{O}(6 \times 8$ hours). The volume in the bag was then transferred to vials, frozen, and lyophilized.

Analytical Characterization of Click Soluble Antigen Arrays-NMR spectra were collected on a Bruker Avance AVIII $500 \mathrm{MHz}$ spectrometer equipped with a dual carbon/ proton cryoprobe (unless otherwise noted), and all samples were dissolved in $650 \mu \mathrm{L}$ of $\mathrm{D}_{2} \mathrm{O}$ for analysis. MestReNova 11.0 was used for NMR data analysis. The amide methyl resonance $(\delta \sim 1.90-2.05 \mathrm{ppm})$ of all ${ }^{1} \mathrm{H}$ NMR spectra was normalized to an integration of 3.0 , and the sum of all other signals in the range of $\delta \sim 1.0-4.0 \mathrm{ppm}$ was used to ratiometrically determine the number of azide functionalization sites during $\mathrm{HA}-\mathrm{N}_{3}$ synthesis.

RP-HPLC and SEC analysis were conducted using a Waters Alliance HPLC system equipped with either a diode array detector or dual wavelength UV/Vis detector. For the quantitative determination of peptide conjugation by RP-HPLC, the following equation was used:

$$
\mathrm{N}_{\text {con }}=\left[\left(\frac{\mathrm{n}_{\text {pep }}}{\mathrm{n}_{\mathrm{HA}}}\right)\left(\frac{\mathrm{V}_{\text {pre }}-\mathrm{V}_{\text {sam }}}{\mathrm{V}_{\text {pre }}}\right)\right]\left(1-\frac{\mathrm{PA}_{\mathrm{t}}}{\mathrm{PA}_{\text {start }}}\right)
$$

where $\mathrm{N}_{\text {con }}=$ number of conjugated peptides per backbone, $\mathrm{n}_{\mathrm{pep}}=$ moles of peptide used in reaction, $\mathrm{n}_{\mathrm{HA}}=$ moles of $\mathrm{HA}-\mathrm{N}_{3}$ used in reaction, $\mathrm{V}_{\text {pre }}=$ total reaction volume before NaAsc is added, $\mathrm{V}_{\text {sam }}=$ volume of "pre-NaAsc" sample removed from reaction mixture, $\mathrm{PA}_{\mathrm{t}}$ $=$ measured peak area of peptide at time $t, \mathrm{PA}_{\text {start }}=$ measured peak area of free peptide before NaAsc is added to the reaction. General chromatographic conditions employed a Waters XBridge $\mathrm{C}_{4}, 3.5 \mu \mathrm{m}, 300 \AA$ stationary phase under ion pairing $\left(0.05 \%\right.$ TFA in $\mathrm{H}_{2} \mathrm{O}$ and $\mathrm{MeCN}$ ) mobile phase conditions, utilizing a linear elution gradient (5-70\%) with detection at $214 \mathrm{~nm}$.

\section{Biophysical Characterization}

Determination of protein concentrations was done with $\varepsilon_{280 \mathrm{~nm}}\left(3 \mathrm{~mL} \cdot \mathrm{g}^{-1} \cdot \mathrm{cm}^{-1}\right)$ for human insulin. For derivatized polymers, the concentrations were determined on a total protein basis (the same absorbance) so that the total concentration of insulin is unchanged. Other polymers and fluorescence concentrations were determined by weight.

Far UV Circular Dichroism-Far UV circular dichroism spectroscopy was perform using an Applied Photophysics Chirascan equipped with a 6-cell holder (Applied Photophysics, Leatherhead, UK). ${ }^{33}$ Proteins were at concentrations of $\sim 0.1 \mathrm{mg} / \mathrm{ml}$, in $10 \mathrm{mM}$ phosphate Buffer $\mathrm{pH} 7.4$ or $\mathrm{pH} 3.0$, in a 1-mm quartz cell. CD was measured from $195-250 \mathrm{~nm}$ and 
using a $1 \mathrm{~nm}$ step size with a two second integration time at each step. Corresponding buffers were subtracted for each sample.

Dynamic Light Scattering-Dynamic light scattering was performed using a DynaPro Plate Reader (Wyatt Technology, Santa Barbara, CA) ${ }^{34}$ Incident light was detected in a backscattering configuration and analyzed with an autocorrelator. Twenty $\mu \mathrm{L}$ of sample, in $10 \mathrm{mM}$ phosphate Buffer $\mathrm{pH}$ 7.4, was placed in a clear-bottomed 384 well plate and read at $20^{\circ} \mathrm{C}$. Samples were measured 5 times with a 15 second acquisition time. Autocorrelation functions were fit using cumulant analysis and intensity averaged values are reported. Errors are reported as standard deviation of 3 replicates.

Intrinsic Fluorescence Spectroscopy-Intrinsic fluorescence was measured as described previously using custom fluorescence plate reader (Fluorescence Innovations, Minneapolis, MN). ${ }^{34}$ Briefly, a $285 \mathrm{~nm}$ laser was used to excite samples and fluorescence was collected at $180^{\circ}$ after passing through a $310 \mathrm{~nm}$ longpass filter to block excitation light. A prism dispersed light onto a CCD to quantify the fluorescence as a function of wavelength. $10 \mu \mathrm{L}$ of sample, in $10 \mathrm{mM}$ phosphate Buffer $\mathrm{pH}$ 7.4, was placed in a 384 well plate and covered with $2 \mu \mathrm{L}$ of silicon oil to prevent sample evaporation. The fluorescence was measured from 10 to $90^{\circ} \mathrm{C}$ with a step-size of $1.25^{\circ} \mathrm{C}$ and an equilibration step of $2 \mathrm{~min}$ between each temperature. The total intensity from 300 to $400 \mathrm{~nm}$ was averaged for each temperature. Error bars represent the standard deviation of 4 replicates.

Mice-Female mice, aged 6-8 weeks, were used in all experiments. VH125.NOD mice express, by virtue of knock-in, the variable heavy-chain region from the insulin specific 125 hybridoma, on the NOD background. Together with endogenous light chains, these mice bear $\sim 3 \%$ insulin reactive B cells in the periphery. $125 \mathrm{Tg}$ mice express both the heavy- and light-chain from the 125 hybridoma, rendering $100 \%$ of their peripheral B cells reactive to insulin. MD4 mice express both a heavy- and light-chain specific for hen-egg lysozyme (HEL); the sole antigen specificity of all B cells in this mouse. Mice were housed and bred at the University of Colorado Denver Anschutz Medical Campus Vivarium or in the Biological Resource Center at National Jewish Health. All experiments involving mice were performed in accordance with the regulations and with approval of the University of Colorado Denver Institutional Animal Care and Use Committee and National Jewish Health.

Tissue harvest-Spleens were harvested in IMDM supplemented with $5 \%$ FCS, 1 mM sodium pyruvate, $50 \mathrm{ug} / \mathrm{mL}$ gentamicin, $100 \mathrm{U} / \mathrm{mL}$ penn/strep, $2 \mathrm{mM} \mathrm{L}$-glutamine, and $5 \mathrm{E}-5$ $\mathrm{M}$ beta-mercaptoethanol; single cell suspensions were prepared by mechanical disruption. RBC's were lysed with $1 \mathrm{~mL}$ ACK ( $150 \mathrm{mM} \mathrm{NH}_{4} \mathrm{Cl}, 10 \mathrm{mM} \mathrm{KHCO}_{3}, 100 \mathrm{mM} \mathrm{Na}_{2}$ EDTA) for $1 \mathrm{~min}$ at room temperature (RT). Cells were subsequently washed and resuspended in either complete medium containing $0.1 \% \mathrm{NaN}_{3}$ or complete medium alone for staining or calcium measurement, respectively. For staining of VH125.NOD + MD4 B cells, B cells were purified via CD43 negative selection before mixing MD4 B cells $(\sim 1 \%)$ into the VH125.NOD B cells.

Flow cytometry-Cells were resuspended at $1 \mathrm{E} 7$ cells $/ \mathrm{mL}$ in cold complete medium containing $0.1 \%$ sodium azide $\left(\mathrm{NaN}_{3}\right) .100 \mu \mathrm{L}$ aliquots containing $1 \mathrm{E} 6$ cells were stained 
with fluorescently-conjugated monoclonal antibodies. Antibodies against the following cellsurface molecules were used: B220 (RA3-6B2; BD), IgM-AF488 (B76) and, CD79b-PE (fab; HM79). B76 and HM79 were produced in the Cambier laboratory and were directly conjugated to fluorochromes according to the manufacture's protocol. For the detection of B cells expressing insulin reactive $B$ cell receptors, cells were first incubated with or without $\mathrm{SAgA}_{\text {Ins }}$ molecules or hyaluronic acid (HA) alone [0.5 ug] for $20 \mathrm{~min}$ at 4 degrees $\mathrm{C}$. After two washes and resuspension in $100 \mu \mathrm{L}$ medium, cells were stained with monomeric biotinylated insulin (ins-bt) (1:50), and HEL-AF488 (1:200) for VH125.NOD + MD4 experiment, for $20 \mathrm{~min}$ at $4^{\circ} \mathrm{C}$. Cells were washed again before adding anti-B220 (APC, PE, or BUV396), anti-IgM, fab anti-CD79b and, fab anti-biotin-AF647. Following final incubation and washing, cells were analyzed on a Fortessa X-20 flow cytometer (BD) and analyzed using FlowJo software (Tree Star).

Calcium mobilization-For measurements of relative intracellular free calcium concentration $\left(\left[\mathrm{Ca}^{2+}\right]_{\mathrm{i}}\right), 125 \mathrm{Tg}$ RBC-lysed splenocytes $(1 \mathrm{E} 7 / \mathrm{mL}$ in complete medium containing $2 \% \mathrm{FCS}$ ) were incubated with or without $\mathrm{SAgA}_{\text {Ins }}$ or $\mathrm{HA}$, for $4 \mathrm{~h}$ at $37^{\circ} \mathrm{C}$ and 5 $\% \mathrm{CO}_{2}$. For an additional hour at RT, cells were simultaneously stained with anti-B220-APC (1:500), fab anti-CD79b-PE (1:500) and, loaded with 5 uM Indo-1 acetoxymethyl. After washing once in medium, cells were resuspended at $5 \mathrm{E} 6$ cells $/ \mathrm{mL}$ in $\mathrm{RT}$ medium in $500 \mu \mathrm{L}$ aliquots. Indo-1 was excited with a 355-nm UV laser, $\mathrm{Ca}^{2+}$-bound Indo-1 was detected with a 379/28 bandpass filter; unbound Indo- 1 was detected with a 524/40 bandpass filter.

Relative free intracellular calcium concentration was determined by calculating the ratio of bound/unbound Indo-1. After acquiring data for $30 \mathrm{~s}$, to establish a baseline, cells were stimulated with the indicated dose of $\mathrm{SAgA}$ Ins molecules, anti-IgM [B76] and/or ionomycin and data collected for an additional $2 \mathrm{~min} 30 \mathrm{sec}$. Relative mean $\left[\mathrm{Ca}_{2+}\right]_{\mathrm{i}}$ was measured on a Fortessa X-20 flow cytometer and analyzed with FlowJo software.

Statistical Analysis-GraphPad Prism was used to perform statistical analysis including sigmoidal nonlinear regression, ordinary one-way or two-way analysis of variance (ANOVA), and unpaired t-test. ANOVA was followed by Tukey's or Sidak's post-hoc test, where appropriate. The threshold for statistical significance was set to $p<0.05$.

\section{RESULTS AND DISCUSSION}

\section{Structural Design of Click Soluble Antigen Arrays}

SAgAs were synthesized by conjugating multiple modified autoantigen (human insulin alkyne; Ins-alk) molecules to $16 \mathrm{kDa}$ hyaluronic acid (HA) to produce the following conjugates: low valency ( 2 insulin per $\mathrm{HA} ;{ }_{1 v} \mathrm{SAgA}_{\text {Ins }}$ ), medium valency (4 insulin per $\mathrm{HA}$; $\mathrm{mv}_{\mathrm{SAgA}} \mathrm{Sns}_{\text {) }}$ and, high valency ( 9 insulin per $\mathrm{HA} ;{ }_{\mathrm{hv}} \mathrm{SAgA}_{\text {Ins }}$ ). $\mathrm{SAgAs}$ are designed to diffuse from the injection site and drain into secondary lymphoid organs to access $B$ cells and other immune cells. Dintizis' reported antigen structural properties that induce tolerance in B cells and provide a useful design framework: $<100 \mathrm{kDa}$, flexible, and highly soluble. We hypothesized that SAgAs with $>5$ insulin molecule per HA would induce anergy in insulin-specific B cells (IBCs). 


\section{Synthesis and Analytical Characterization of Click Soluble Antigen Arrays}

Both qualitative and quantitative analytical techniques were used to characterize SAgAs and their components. The amine pegylated azide $\left(\mathrm{H}_{2} \mathrm{~N}-\mathrm{PEG}_{3}-\mathrm{N}_{3}\right)$ was conjugated to $\mathrm{HA}$ via (1Ethyl-3-(3-dimethylaminopropyl)-carbodiimide)/N-hydroxysuccinimide (EDC/NHS) coupling chemistry. ${ }^{1} \mathrm{H}$ NMR was used to quantify azide functionalization of HA-azide revealing an average of 41 azides per HA (Figure 1). This was done by integrating a peak from the HA backbone, highlighted in yellow (Figure $1 \mathrm{~B} ;\left(\delta\left({ }^{1} \mathrm{H}\right) \approx 2.0 \mathrm{ppm}\right.$ ), and a peak in HA-azide $\left(\mathrm{HA}-\mathrm{N}_{3}\right.$ ) that corresponds to a methylene peak, highlighted in blue (Figure 1A; $\left(\delta\left({ }^{1} \mathrm{H}\right) \approx 2.5 \mathrm{ppm}\right)$. Resonance peaks $\delta\left({ }^{1} \mathrm{H}\right) \approx 2.7 \mathrm{ppm}$ or $2.9 \mathrm{ppm}$ in Figure $1 \mathrm{~B}$ correspond to methylene protons in the linker can also be used to determine conjugation efficiency. Due to manual integration performed to determine conjugation and the heterogeneity of HA, this analysis should be considered semiquantitative. Modification of the autoantigen human insulin was conducted by conjugating an alkyne linker (Propargyl-N-hydroxysuccinimidyl ester) via NHS chemistry to furnish insulin-alkyne (Ins-Alk). LC-MS verified the successful synthesis of Ins-Alk and further characterization of the modified protein led to the identification of the site of modification. LC/MS analysis determined that two species of InsAlk existed. Either B29 lysine was modified or modification occurred on the N-terminus on the A chain (Figure S1A; S1B), either site being acceptable for retaining accessibility of the bulk of the insulin structure.

$\mathrm{CuAAC}$ reaction conditions were used to conjugate Ins-alk to $\mathrm{HA}-\mathrm{N}_{3}$ to produce prototype low valency ${ }_{1 v} \mathrm{SAgA}_{\text {Ins }}$ (2 Ins per HA). Next, medium valency ${ }_{m v} \mathrm{SAgA}_{\text {Ins }}$ (4 Ins per HA) and high valency hv $\mathrm{SAgA}_{\text {Ins }}$ (9 Ins per HA) were analyzed by reverse-phase analytical highperformance liquid chromatography (RP-HPLC) to determine the molecular weight and protein conjugation (Figure S2; See Equation 1). The complete conjugation of Ins-Alk to HA-N 3 for ${ }_{m v} S A g A_{\text {Ins and hv }} \mathrm{SAgA}_{\text {Ins }}$ can be seen in both Figure S2A and Figure S2B. It should be noted that two aliquots from each reaction were taken before Sodium Ascorbate (NaAsc) was added. One aliquot was used to determine total Ins-Alk in solution and the second was analyzed under the same conditions as the reaction mixture without NaAsc to determine protein degradation over $24 \mathrm{~h}(\sim 1$ Ins-Alk).

${ }^{1} \mathrm{H} /{ }^{13} \mathrm{C}$ Heteronuclear Single Quantum Coherence (HSQC) NMR spectroscopy was used to qualitatively confirm the homopropargyl linker on the Ins-Alk (green resonance; $\delta\left({ }^{1} \mathrm{H}\right) \approx 2.9$ ppm, $\delta\left({ }^{13} \mathrm{C}\right) \approx 70 \mathrm{ppm}$; Figure $\left.2 \mathrm{~A}, 2 \mathrm{C}\right)$. When both human insulin (red resonance) and InsAlk (green resonance) HSQC spectra were superimposed, some residue resonance signals pointed towards little to no structural change (Figure 2B, 2D; black square), while distinct conformational differences were predominately seen in the aromatic region for Ins-Alk (Figure 2B; black circles). These differences suggested the installation of the homopropargyl handle caused a buried aromatic amino acid (i.e. phenylalanine) to become solvent exposed, thus becoming detectable by NMR. Finally, HSQC analysis revealed the absence of the unique resonance signal for the homopropargyl linker on Ins-Alk $\left(\delta\left({ }^{1} \mathrm{H}\right) \approx 2.9 \mathrm{ppm}, \delta\left({ }^{13} \mathrm{C}\right)\right.$ $\approx 70 \mathrm{ppm}$; black triangle) in both the ${ }_{\mathrm{mv}} \mathrm{SAgA}_{\mathrm{Ins}}$ and ${ }_{\mathrm{hv}} \mathrm{SAgA}_{\text {Ins }}$ spectrum (Figure $2 \mathrm{E}$ and $2 \mathrm{~F}$ ), thus confirming the final products contained only the conjugated protein.

Circular Dichroism (CD) analysis of human insulin was consistent with previously reported alpha helical secondary structure (Figure 3A, 3B). SAgA Ins mostly retained alpha helical 
secondary structure in both neutral ( $\mathrm{pH}$ 7.4) and acid media ( $\mathrm{pH} 3.0)$, however, ${ }_{\mathrm{hv}} \mathrm{SAgA}$ Ins appeared to lose significant secondary structure under acidic conditions (Figure 3A, 3B). Further analysis of $\mathrm{CD}$ data revealed greater loss of alpha helical structure for ${ }_{\mathrm{hv}} \mathrm{SAgA}_{\mathrm{Ins}}$ when compared to ${ }_{\mathrm{mv}} \mathrm{SAgA}_{\mathrm{Ins}}$ in both acidic and neutral solutions (Figure 3A, 3B). When directly studying the effect of $\mathrm{pH}$ on each $\mathrm{SAgAs}$, secondary structure was compromised at lower $\mathrm{pH}$ when compared to neutral conditions. HSQC NMR analysis in combination with $\mathrm{CD}$ data may explain the loss of secondary structure of $\mathrm{SAgA}$ Ins when compared to native human insulin. Alkyne modification resulted in a physical change in protein structure that permitted hydrophobic residues to be detected using HSQC NMR. These hydrophobic resides such as tyrosine may interfere with a lpha helical structure. In addition, acidic amino acids (i.e. aspartic acid and glutamic acid) become more protonated at lower $\mathrm{pH}$, which may disrupt salt bridges which could alter the peptide secondary structure.

Melting of the secondary structure as monitored by $\mathrm{CD}$ (Figure 3C) shows a minor transition in the insulin secondary structure $\left(\mathrm{T}_{\mathrm{m}} \sim 55^{\circ} \mathrm{C}\right)$ which is substantially reduced when the protein is conjugated to HA. A temperature melt plot based on intrinsic fluorescence (Figure 3D) showed only weak evidence of the transition for insulin alone with the modified forms manifesting its absence. This may be explained by the fact that insulin contains three disulfide bonds which strongly stabilize the protein. The loss of the transition in the conjugated form suggest some further stabilization of the protein. Finally, dynamic light scattering showed a significant size increase for the conjugated forms (Table 1). A large increase in size for ${ }_{h v} \mathrm{SAgA}_{\text {Ins }}$ may correlate with the partial loss in alpha helical structure (Figure 3), where the $\mathrm{SAgA}_{\text {Ins }}$ would now favor more extended forms as well as intermolecular interactions that may lead to self-association.

\section{$S A g A_{\text {Ins }}$ binding and effects on ex vivo IBCs}

Insulin-SAgAs bind specifically to insulin reactive $B$ cells-To assess the immunological effects of multimeric, insulin-polymer ( $\mathrm{SAgA}$ Ins $)$ molecules, we first determined if $\mathrm{SAgA}_{\text {Ins }}$ are capable of ligating $\mathrm{B}$ cell receptors (BCR) on the surface of IBCs. To this end, we utilized B cells from $125 \mathrm{Tg}$ mice in which, by virtue of heavy- and lightchain knock-in, harbor peripheral B cells with an insulin reactivity-fixed receptor repertoire. Red blood cell (RBC)-lysed, 125Tg splenocytes were first incubated with or without $\mathrm{SAgA}_{\text {Ins }}$ (low or high avidity) or hyaluronic acid (HA) alone for $20 \mathrm{~min}$, at $4{ }^{\circ} \mathrm{C}$, in complete medium containing $0.1 \% \mathrm{NaN}_{3}$. Staining under these conditions prevents the internalization of ligated BCR. After being washed, cells were exposed to monomeric biotinylated insulin (ins-bt), washed, and subsequently stained with antibodies against B220 (B cells), CD79b (BCR) and, immunoglobulin (IgM, BCR) together with anti-biotin. Depicted in Figure 4A, pre-treatment with $\mathrm{SAgA}_{\text {Ins }}$, but not HA alone, blocked binding of ins-bt. Staining in which ins-bt was omitted served as a positive control and staining with no $\mathrm{SAgA}_{\text {Ins }}$ pre-treatment served as a negative control. In addition, neither $\mathrm{SAgA}_{\text {Ins }}$ nor ins-bt bound to non- (B220-) B cells (data not shown). In anticipation of experiments in which we re-stimulate $\mathrm{SAgA}$ Ins tolerized IBCs, we wanted to ensure that $\mathrm{SAgA}_{\text {Ins }}$ binding to the $\mathrm{BCR}$ did not obscure binding of BCR stimulating antibodies. In this case, cells previously exposed to the $\mathrm{SAgA} \mathrm{A}_{\text {Ins }}$ where subsequently stained with anti-IgM [B76] and anti-CD79b [HM79]. No change in staining intensity was detected for anti-BCR antibodies in cells 
pretreated with $\mathrm{SAgA}_{\text {Ins }}$ (Figure 4B). Finally, to address $\mathrm{SAgA}$ Ins binding in a more physiologic, clonally diverse setting, we utilized B cells (CD43-) purified from spleens of VH125.NOD mice in which $\sim 1-3 \%$ of peripheral B cells bind insulin. To ensure specificity, MD4 B cells (HEL reactive) were mixed in at approximately the same frequency as IBCs. As before, cells were pretreated with $\mathrm{SAgA}$ Ins or $\mathrm{HA}$ alone before being stained with insbt/fab anti-bt-AF647 and HEL-AF488. As displayed in Figure 4C, SAgA Ins blocked binding of ins-bt but not HEL-AF488.

\section{In vitro incubation of IBCs with insulin-SAgA leads to decreased expression of $B C R$ and desensitization of the BCR to additional stimulation- $S A g A_{\text {Ins }}$ are}

designed as potential therapeutic agents for preventing the development of T1D. B cells are required for the development of T1D in mice and have been strongly implicated in human disease, probably functioning as antigen presenting cells needed for $\mathrm{T}$ cell activation in the pancreas. ${ }^{35}$ Depletion of B cells with an anti-CD20 antibody (rituximab) has been shown to delay the progression of disease in humans. ${ }^{36}$ Similarly, tolerization of peripheral B cells by chronic BCR stimulation has been observed to delay disease onset in mice. ${ }^{37}$ Following from this, we hypothesized that tolerizing antigen-(insulin) specific B cells may prove to be similarly efficacious in preventing T1D progression. Antigen specific tolerization comes with the added benefit of allowing the remainder of the $\mathrm{B}$ cell compartment to remain active for fighting infection and responding to vaccination.

To determine if $\mathrm{SAgA}_{\text {Ins }}$ are capable of tolerizing IBCs, we again utilized B cells from the $125 \mathrm{Tg}$ mouse. We first measured intracellular calcium mobilization in response to acute stimulation with $\mathrm{SAgA}_{\text {Ins }}$ (Figure 5A). Anti-IgM and HA alone were used as positive and negative controls, respectively. $\mathrm{SAgA}$ Ins stimulated a similar calcium flux in comparison to stimulation with anti-IgM (note that $125 \mathrm{Tg}$ B cells exclusively express IgM). Next, we incubated $125 \mathrm{Tg}$ IBCs with or without $\mathrm{SAg} \mathrm{A}_{\text {Ins }}$ or $\mathrm{HA}$ alone for $\sim 5 \mathrm{~h}$ before measuring surface BCR expression and calcium mobilization (Figure 5B, 5C). Pre-incubation with $\mathrm{SAgA}_{\text {Ins }}$ led to decreased expression of surface $\mathrm{BCR}$, as measured by CD79b, reminiscent of chronically stimulated, anergic B cells found in mice and humans (Figure 5B). ${ }^{35}$ Preincubation with $\mathrm{SAg} \mathrm{A}_{\mathrm{Ins}}$, but not HA, rendered IBC's refractory to re-stimulation through the BCR (Figure 5C). This inhibition was not due to masking of the epitope on the BCR recognized by $\mathrm{B} 76$ (Figure 5B) and was independent of the $\mathrm{SAgA}_{\text {Ins }}$ induced decrease in surface BCR (gating in Figure 5B). In addition, cells incubated with $\mathrm{SAgA}_{\text {Ins }}$ remained refractory to a 5-fold excess of anti-IgM stimulation (Figure 5C dashed lines), which as expected increased calcium response in untreated or HA treated cells (Figure 5A, 5C). Finally, $\mathrm{SAgA}$ Ins induced desensitization of the BCR is independent of Inositol trisphosphate receptor (IP3) receptor-mediated release of intercellular calcium stores, since stimulation with the calcium ionophore, ionomycin, resulted in similar calcium influx in $\mathrm{SAgA}_{\mathrm{Ins}}$ treated, HA treated, and untreated cells. This suggests that $\mathrm{SAgA}_{\text {Ins }}$-induced tolerance of IBCs may rely on mechanisms observed to be operative in anergic B cells found in mice and humans. ${ }^{38}$ 


\section{CONCLUSIONS}

SAgAs were successfully synthesized by conjugating multiple modified autoantigen human insulin (Ins-alk) molecules to the $16 \mathrm{kDa}$ linear polymer hyaluronic acid (HA) to produce the following conjugates: low valency ${ }_{1 v} \mathrm{SAgA}_{\text {Ins }}$ ( 2 insulin per $\mathrm{HA}$ ), medium valency ${ }_{m v} \mathrm{SAgA}_{\text {Ins }}$ (4 insulin per HA)and, high valency ${ }_{\mathrm{hv}} \mathrm{SAgA}_{\text {Ins }}$ (9 insulin per HA). Insulin conjugated to $\mathrm{SAgA}_{\text {Ins }}$ maintained alpha helical structure at physiological $\mathrm{pH}$. Different valency $\mathrm{SAgA}_{\text {Ins }}$ did not appear to modulate biologic activity, producing similar levels of receptor blockade and $\mathrm{BCR}$ desensitization. $\mathrm{SAg} \mathrm{A}_{\text {Ins }}$ bound specifically to IBCs without blocking epitopes recognized by antibodies against the BCR. The inability of $\mathrm{SAgA}_{\mathrm{Ins}^{-}}$ treated IBCs to respond to BCR stimulation could potentially be explained simply by blocking of BCR epitopes recognized by the stimulating antibodies. Thus, the mechanism was more deeply assessed. Pre-incubation of IBCs (125Tg) with $\mathrm{SAgA}_{\mathrm{Ins}}$, but not HA, rendered the BCR desensitized to re-stimulation. This effect was independent of $\mathrm{SAgA}_{\mathrm{Ins}}$ induced decrease in BCR expression and was also independent of IP3R-mediated intracellular calcium release. Activity was dependent on $\mathrm{SAgA}_{\text {Ins }}$ binding to $\mathrm{BCR}$ on the surface of IBCs and its ability to acutely stimulate these cells. SAgA $\mathrm{Ins}_{\text {Ins }}$ silenced IBCs by inducing refractory $\mathrm{B}$ cell receptor signaling resulting in a mechanism of immune tolerance similar to B cell anergy, thus mimicking a known mechanism of peripheral tolerance.

\section{Supplementary Material}

Refer to Web version on PubMed Central for supplementary material.

\section{ACKNOWLEDGEMENTS}

We gratefully acknowledge support from the National Institutes of Health Graduate Training Program in Dynamic Aspects of Chemical Biology Grant (T32 GM008545) from the National Institutes of General Medical Sciences (M.L.). Additionally, we thank the Macromolecule and Vaccine Stabilization Center and the KU NMR Lab.

\section{REFERENCES}

(1). Chan A, and Schutte AJ (2014) Interview: Experiences targeting B cells for the treatment of multiple sclerosis, Immunotherapy 6, 127-130. [PubMed: 24491086]

(2). Lehmann-Horn K, Kronsbein HC, and Weber MS (2013) Targeting B cells in the treatment of multiple sclerosis: recent advances and remaining challenges, Ther Adv Neurol Disord, 1756285612474333.

(3). Wong FS, Wen L, Tang M, Ramanathan M, Visintin I, Daugherty J, Hannum LG, Janeway CA, and Shlomchik MJ (2004) Investigation of the role of B-cells in type 1 diabetes in the NOD mouse, Diabetes 53, 2581-2587. [PubMed: 15448087]

(4). Serreze DV, Fleming SA, Chapman HD, Richard SD, Leiter EH, and Tisch RM (1998) B lymphocytes are critical antigen-presenting cells for the initiation of T cell-mediated autoimmune diabetes in nonobese diabetic mice, J. Immunol. 161, 3912-3918. [PubMed: 9780157]

(5). Silveira PA, Johnson E, Chapman HD, Bui T, Tisch RM, and Serreze DV (2002) The preferential ability of B lymphocytes to act as diabetogenic APC in NOD mice depends on expression of selfantigen-specific immunoglobulin receptors, Eur. J. Immunol. 32, 3657-3666. [PubMed: 12516557]

(6). Greeley SAW, Moore DJ, Noorchashm H, Noto LE, Rostami SY, Schlachterman A, Song HK, Koeberlein B, Barker CF, and Naji A (2001) Impaired activation of islet-reactive CD4 T cells in pancreatic lymph nodes of B cell-deficient nonobese diabetic mice, J. Immunol. 167, 4351-4357. [PubMed: 11591759] 
(7). Vehik K, Beam CA, Mahon JL, Schatz DA, Haller MJ, Sosenko JM, Skyler JS, Krischer JP, and Group TNHS (2011) Development of autoantibodies in the TrialNet natural history study, Diabetes Care 34, 1897-1901. [PubMed: 21750277]

(8). Bennett J, O'Connor K, Bar-Or A, Zamvil S, Hemmer B, Tedder T, von Büdingen H, Stuve O, Yeaman M, and Smith T (2015) B lymphocytes in neuromyelitis optica. Neurol Neuroimmunol Neuroinflamm 2: e104. [PubMed: 25977932]

(9). Quan C, ZhangBao J, Lu J, Zhao C, Cai T, Wang B, Yu H, Qiao J, and Lu C (2015) The immune balance between memory and regulatory B cells in NMO and the changes of the balance after methylprednisolone or rituximab therapy, J. Neuroimmunol. 282, 45-53. [PubMed: 25903728]

(10). Fernandez-Nebro A, de la Fuente JM, Carreno L, Izquierdo MG, Tomero E, Rúa-Figueroa I, Hernández-Cruz B, Narváez J, Ucar E, and Olivé A (2012) Multicenter longitudinal study of Blymphocyte depletion in refractory systemic lupus erythematosus: the LESIMAB study, Lupus 21, 1063-1076. [PubMed: 22786985]

(11). Vital EM, Dass S, Buch MH, Henshaw K, Pease CT, Martin MF, Ponchel F, Rawstron AC, and Emery P (2011) B cell biomarkers of rituximab responses in systemic lupus erythematosus, Arthritis Rheumatol. 63, 3038-3047.

(12). Boster A, Ankeny DP, and Racke MK (2010) The potential role of B cell-targeted therapies in multiple sclerosis, Drugs 70, 2343-2356. [PubMed: 21142258]

(13). Oh S, Cudrici C, Ito T, and Rus H (2008) B-cells and humoral immunity in multiple sclerosis. Implications for therapy, Immunol Res 40, 224-234. [PubMed: 17960498]

(14). Bates D (2011) Treatment effects of immunomodulatory therapies at different stages of multiple sclerosis in short-term trials, Neurology 76, S14-S25.

(15). Feldmann M, and Steinman L (2005) Design of effective immunotherapy for human autoimmunity, Nature 435, 612. [PubMed: 15931214]

(16). Miller SD, Turley DM, and Podojil JR (2007) Antigen-specific tolerance strategies for the prevention and treatment of autoimmune disease, Nat. Rev. Immunol. 7, 665. [PubMed: 17690713]

(17). Akdis M, and Akdis CA (2007) Mechanisms of allergen-specific immunotherapy, J. Allergy Clin. Immunol. 119, 780-789. [PubMed: 17321578]

(18). Dintzis H, Dintzis R, and Vogelstein B (1976) Molecular determinants of immunogenicity: the immunon model of immune response, Proc. Natl. Acad. Sci. U.S.A. 73, 3671-3675. [PubMed: 62364]

(19). Brunswick M, Finkelman F, Highet P, Inman J, Dintzis HM, and Mond J (1988) Picogram quantities of anti-Ig antibodies coupled to dextran induce B cell proliferation, J. Immunol. 140, 3364-3372. [PubMed: 2452184]

(20). Dintzis RZ, Okajima M, Middleton MH, and Dintzis HM (1990) Inhibition of antibody formation by receptor cross-linking: the molecular characteristics of inhibitory haptenated polymers, Eur. J. Immunol. 20, 229-232. [PubMed: 1689663]

(21). Reim JW, Symer DE, Watson DC, Dintzis RZ, and Dintzis HM (1996) Low molecular weight antigen arrays delete high affinity memory B cells without affecting specific T-cell help, Mol. Immunol. 33, 1377-1388. [PubMed: 9171897]

(22). Roozendaal R, Mebius RE, and Kraal G (2008) The conduit system of the lymph node, Int. Immunol. 20, 1483-1487. [PubMed: 18824503]

(23). Rantakari P, Auvinen K, Jäppinen N, Kapraali M, Valtonen J, Karikoski M, Gerke H, Iftakhar-EKhuda I, Keuschnigg J, and Umemoto E (2015) The endothelial protein PLVAP in lymphatics controls the entry of lymphocytes and antigens into lymph nodes, Nat. Immunol. 16, 386. [PubMed: 25665101]

(24). Hartwell BL, Martinez-Becerra FJ, Chen J, Shinogle H, Sarnowski M, Moore DS, and Berkland C (2016) Antigen-Specific Binding of Multivalent Soluble Antigen Arrays Induces Receptor Clustering and Impedes B Cell Receptor Mediated Signaling, Biomacromolecules 17, 710-722. [PubMed: 26771518]

(25). Hartwell BL, Smalter Hall A, Swafford D, Sullivan BP, Garza A, Sestak JO, Northrup L, and Berkland C (2016) Molecular Dynamics of Multivalent Soluble Antigen Arrays Support a Two- 
Signal Co-delivery Mechanism in the Treatment of Experimental Autoimmune Encephalomyelitis, Mol. Pharm. 13, 330-343. [PubMed: 26636828]

(26). Northrup L, Sestak JO, Sullivan BP, Thati S, Hartwell BL, Siahaan TJ, Vines CM, and Berkland C (2014) Co-delivery of autoantigen and b7 pathway modulators suppresses experimental autoimmune encephalomyelitis, AAPS J. 16, 1204-1213. [PubMed: 25297853]

(27). Sestak J, Mullins M, Northrup L, Thati S, Forrest ML, Siahaan TJ, and Berkland C (2013) Single-step grafting of aminooxy-peptides to hyaluronan: a simple approach to multifunctional therapeutics for experimental autoimmune encephalomyelitis, J. Control. Release 168, 334-340. [PubMed: 23541930]

(28). Sestak JO, Fakhari A, Badawi AH, Siahaan TJ, and Berkland C (2014) Structure, size, and solubility of antigen arrays determines efficacy in experimental autoimmune encephalomyelitis, AAPS J. 16, 1185-1193. [PubMed: 25193268]

(29). Sestak JO, Sullivan BP, Thati S, Northrup L, Hartwell B, Antunez L, Forrest ML, Vines CM, Siahaan TJ, and Berkland C (2014) Codelivery of antigen and an immune cell adhesion inhibitor is necessary for efficacy of soluble antigen arrays in experimental autoimmune encephalomyelitis, Mol Ther Methods Clin Dev 1.

(30). Thati S, Kuehl C, Hartwell B, Sestak J, Siahaan T, Forrest ML, and Berkland C (2015) Routes of administration and dose optimization of soluble antigen arrays in mice with experimental autoimmune encephalomyelitis, J. Pharm. Sci. 104, 714-721. [PubMed: 25447242]

(31). Hartwell BL, Pickens CJ, Leon M, and Berkland C (2017) Multivalent Soluble Antigen Arrays Exhibit High Avidity Binding and Modulation of B Cell Receptor-Mediated Signaling to Drive Efficacy against Experimental Autoimmune Encephalomyelitis, Biomacromolecules 18, 18931907. [PubMed: 28474886]

(32). Hartwell BL, Pickens CJ, Leon M, Northrup L, Christopher MA, Griffin JD, Martinez-Becerra F, and Berkland C (2018) Soluble antigen arrays disarm antigen-specific B cells to promote lasting immune tolerance in experimental autoimmune encephalomyelitis, J. Autoimmun.

(33). Wei Y, Wahome N, Kumar P, Whitaker N, Picking WL, and Middaugh CR (2018) Effect of Phosphate Ion on the Structure of Lumazine Synthase, an Antigen Presentation System From Bacillus anthracis, J. Pharm. Sci. 107, 814-823. [PubMed: 29045884]

(34). Wei Y, Larson NR, Angalakurthi SK, and Russell Middaugh C (2018) Improved Fluorescence Methods for High-Throughput Protein Formulation Screening, SLAS Technol, 2472630318780620.

(35). Pescovitz MD, Greenbaum CJ, Bundy B, Becker DJ, Gitelman SE, Goland R, Gottlieb PA, Marks JB, Moran A, and Raskin P (2013) B-lymphocyte depletion with rituximab and beta-cell function: two-year results, Diabetes Care, DC_130626.

(36). Pescovitz MD, Greenbaum CJ, Krause-Steinrauf H, Becker DJ, Gitelman SE, Goland R, Gottlieb PA, Marks JB, McGee PF, and Moran AM (2009) Rituximab, B-lymphocyte depletion, and preservation of beta-cell function, N. Engl. J. Med. 361, 2143-2152. [PubMed: 19940299]

(37). Hardy IR, Anceriz N, Rousseau F, Seefeldt MB, Hatterer E, Irla M, Buatois V, Chatel LE, Getahun A, and Fletcher A (2014) Anti-CD79 antibody induces B cell anergy that protects against autoimmunity, J. Immunol, 1302672.

(38). Cambier JC, Gauld SB, Merrell KT, and Vilen BJ (2007) B-cell anergy: from transgenic models to naturally occurring anergic B cells?, Nat. Rev. Immunol. 7, 633. [PubMed: 17641666] 


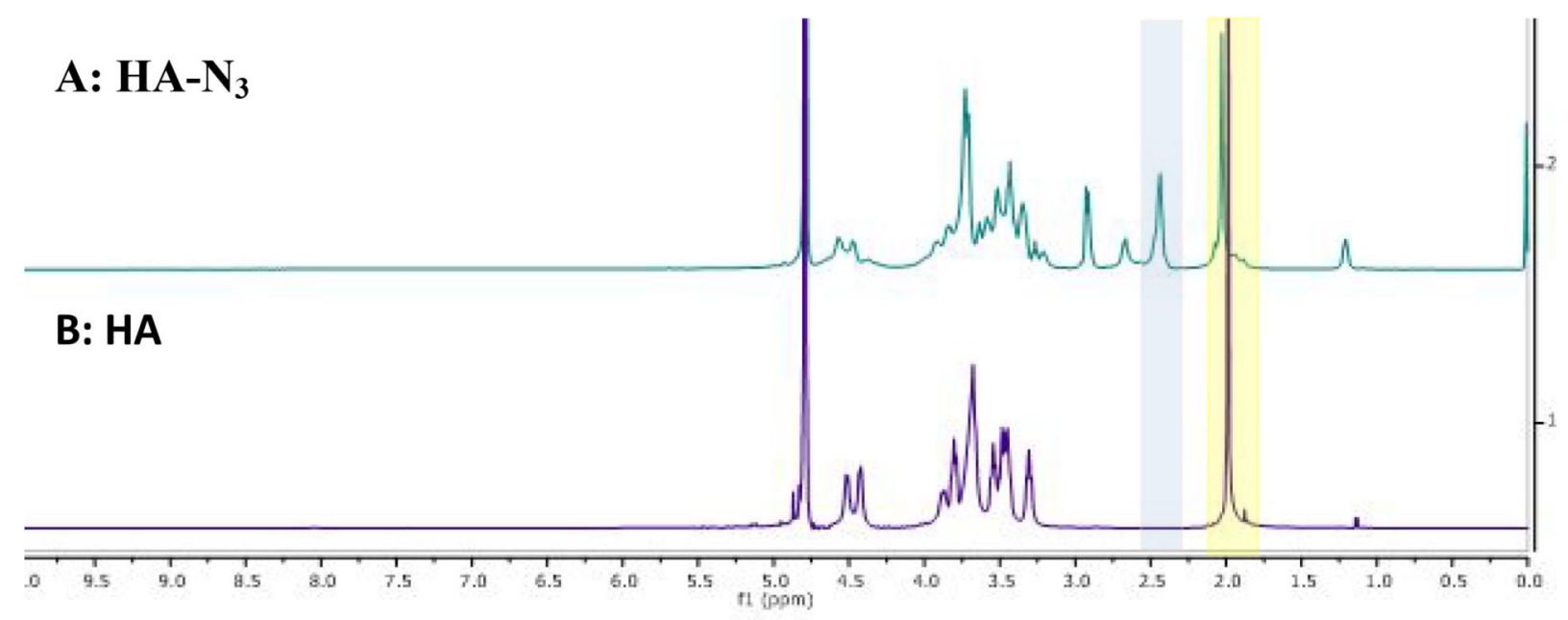

Figure 1:

${ }^{1} \mathrm{H}$ NMR spectra of hyaluronic acid (HA) and hyaluronic acid azide $\left(\mathrm{HA}-\mathrm{N}_{3}\right)$. Peaks used to determine the average number of azides in $\mathrm{HA}-\mathrm{N}_{3}$ are highlighted in yellow and blue. 

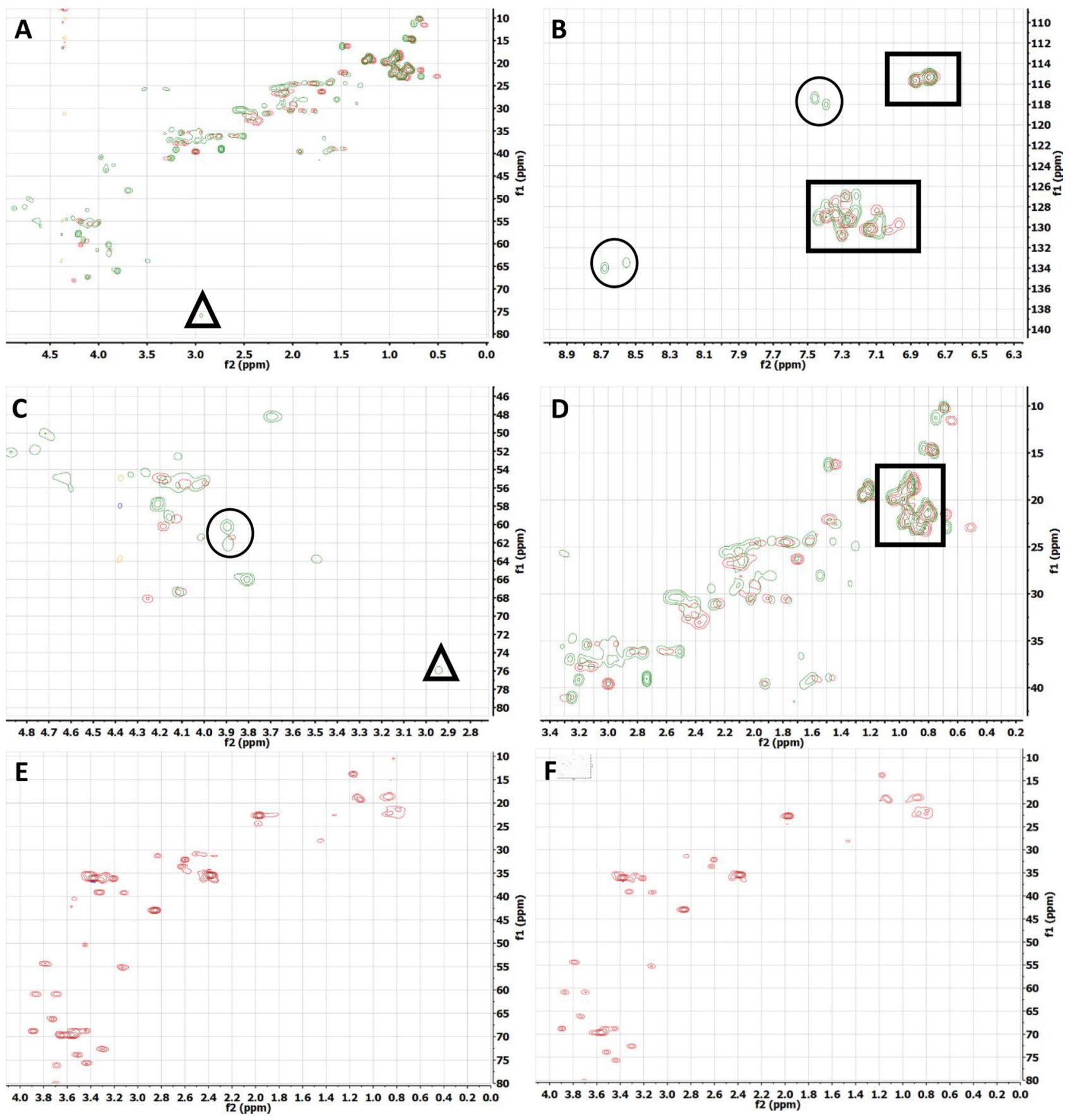

\section{Figure 2:}

Overlapped HSQC NMR spectra of insulin (red resonance) and insulin alkyne (green resonance) (A-D). Multivalent SAgAs ( $\left.\mathrm{mv}_{\mathrm{SAgA}} \mathrm{Sns}\right) \mathrm{E}$ and $\left({ }_{\mathrm{hv}} \mathrm{SAgA}_{\text {Ins }}\right) \mathrm{F}$ show no resonances from the alkyne peak found only Ins-Alk present in either of the final compounds. The alkyne peak found in Ins-Alk is not found in any of the products, which implies no residual unconjugated insulin. HSQC NMR of A uses a black triangle to highlight the terminal alkyne proton in Ins-Alk. B shows more available aromatic residues in Ins-alk (green) when compared to insulin. $\mathrm{C}$ and $\mathrm{D}$ highlight similarities (black squares) and 
differences (black circles) between insulin alkyne (green resonance) and insulin (red resonance). 

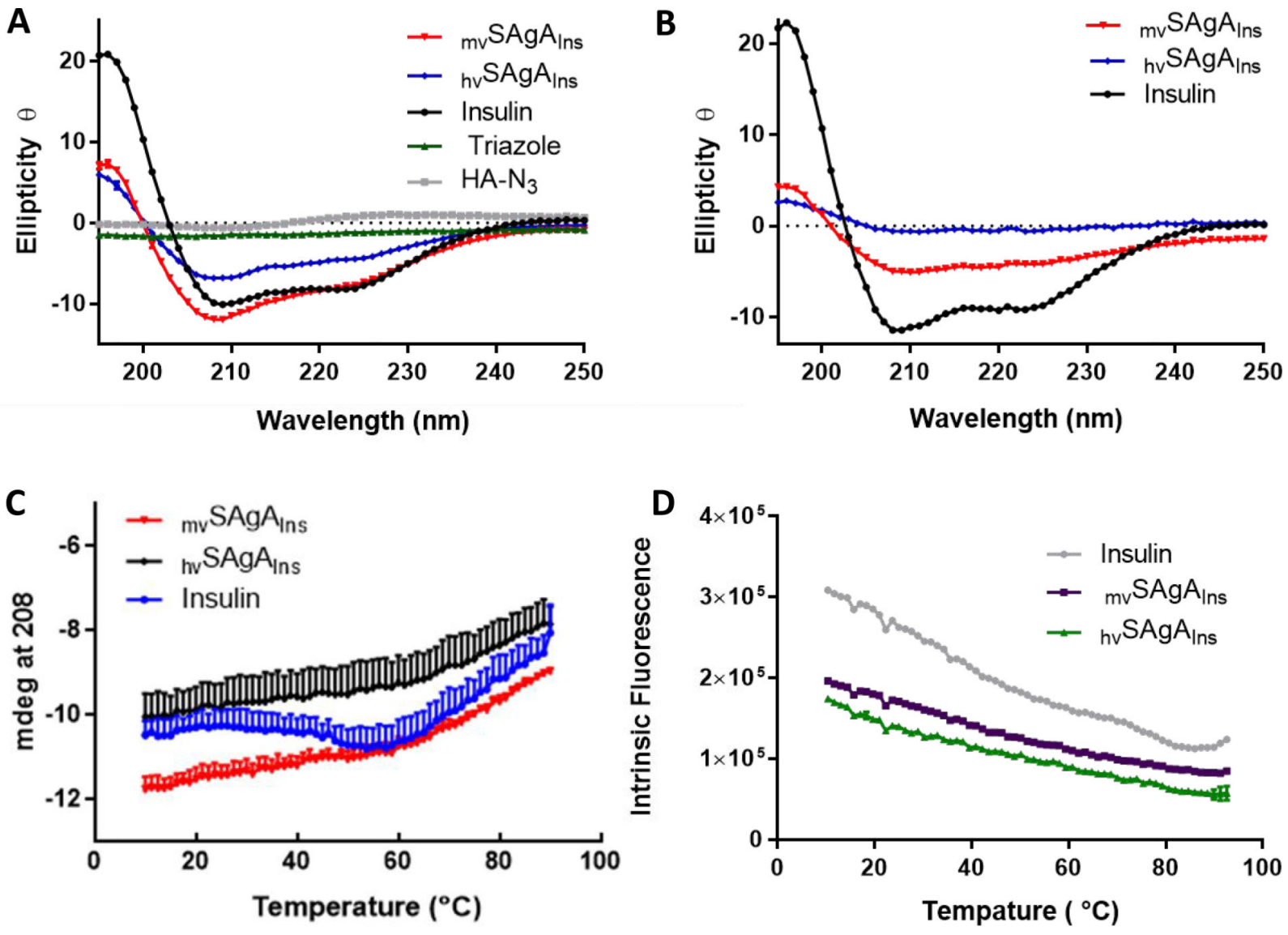

Figure 3:

Far-UV Circular Dichroism of (A): ${ }_{m v} \mathrm{SAgA}_{\text {Ins }}$ and ${ }_{\mathrm{hv}} \mathrm{SAgA}_{\text {Ins }}$ in phosphate buffer $\mathrm{pH} 7.4$; (B): ${ }_{m v} \mathrm{SAgA}_{\text {Ins }}$ and ${ }_{\mathrm{hv}} \mathrm{SAgA}_{\text {Ins }}$ in water $\mathrm{pH} 3.0$; (C): medium and high valency $\mathrm{SAgAs}$ phosphate $\mathrm{pH} 7.4$ temperature melt; (D): Intrinsic fluorescent temperature melt of SAgAs in phosphate $\mathrm{pH} 7.4$. 

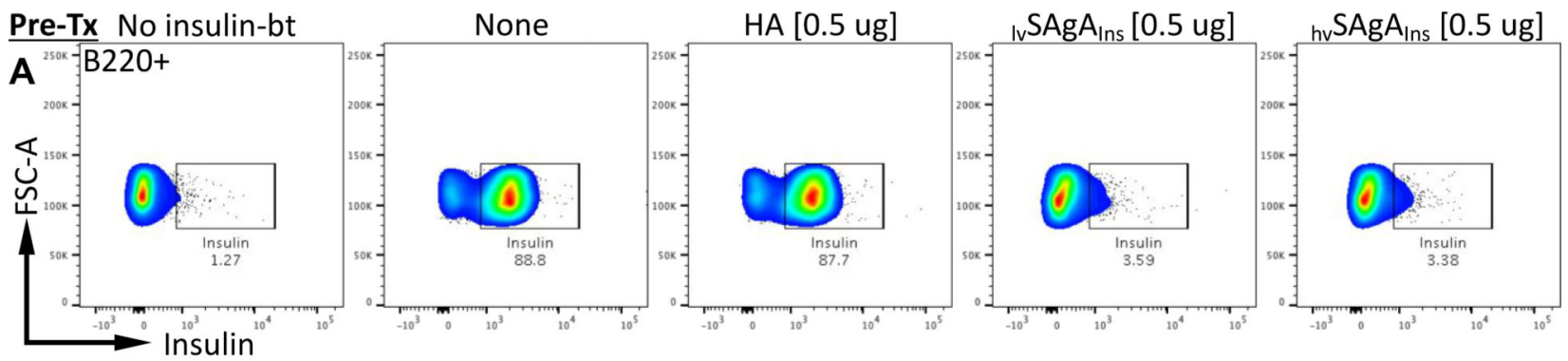

Pre-Tx [0.5 ug]
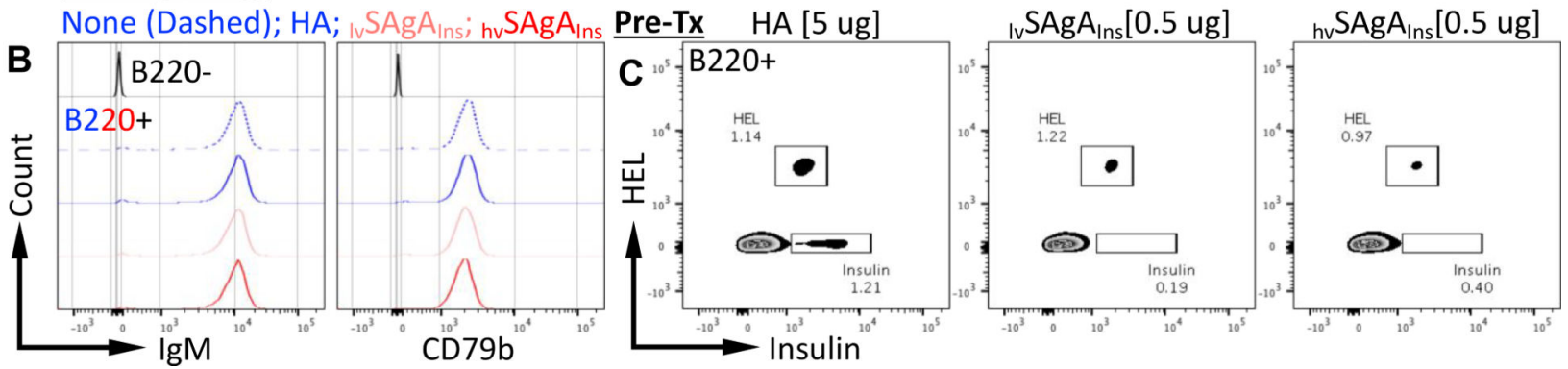

Figure 4:

Specific binding of $\mathrm{SAgA}_{\text {Ins }}$ to insulin binding cells (IBCs). Both low-avidity (1v $\mathrm{SAgA}$ Ins) and high-avidity ( ${ }_{\mathrm{hv}} \mathrm{SAgA} \mathrm{Ans}_{\mathrm{Ins}}$ ) molecules, but not hyaluronic acid (HA) alone, block binding of monomeric biotinylated-insulin to insulin-specific (B220+;125Tg) B cells (A.).

Pretreatment of $125 \mathrm{Tg} B$ cells with either $\mathrm{SAgA}$ Ins or hyaluronic acid does not block epitopes recognized by anti-IgM [B76] nor anti-CD79b [HM79] (B.). SAgA $\mathrm{Ans}_{\text {Ins }}$ molecules block binding of insulin-bt to insulin specific B cells (CD43-, B220+;VH125.NOD) but not binding of hen egg lysozyme (HEL) to HEL specific B cells (CD43-, B220+;MD4) when both cell types are present at similar frequencies (C.). Layout gate frequencies represent percent of B cells (B220+). Data are representative of at least 3 independent experiments. 
Stimulus [5 ug]

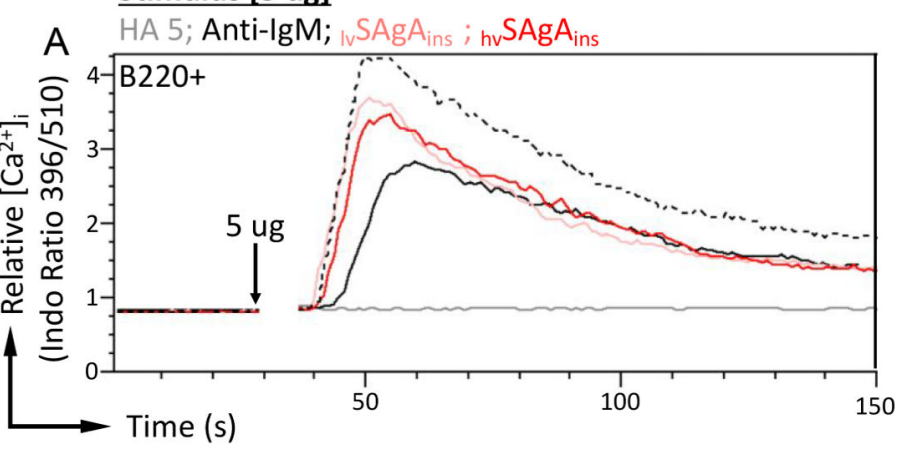

B

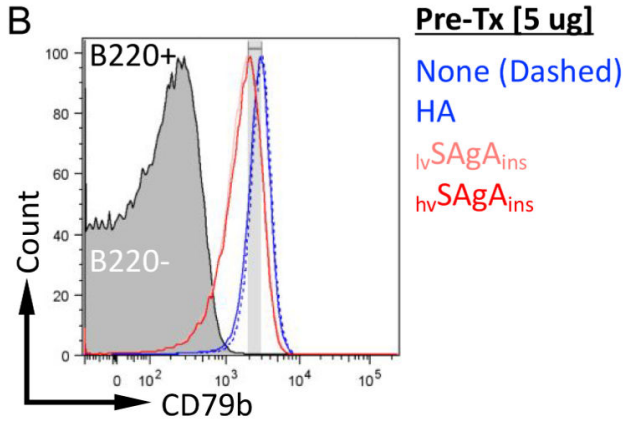

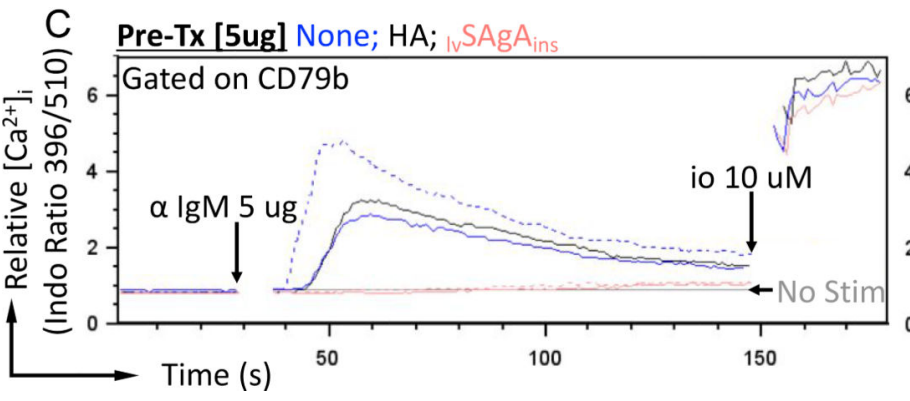

Pre-Tx [5ug] None; HA; $\mathrm{hV}_{\mathrm{SAg}} \mathrm{A}_{\text {ins }}$

Figure 5:

$\mathrm{SAgA}_{\text {Ins }}$ effects on ex-vivo, insulin-binding cells (IBCs). SAgA Ins molecules, but not hyaluronic acid (HA) alone, are capable of aggregating $B$ cell receptors (BCR) on insulin specific B cells (125Tg) and stimulating extracellular calcium influx (A.). 5 hour preincubation of IBCs $\left(125 \mathrm{Tg}\right.$ ) with $\mathrm{SAgA}_{\text {Ins }}$, but not HA, leads to decreased expression of $\mathrm{BCR}$ on the surface of IBCs (B.). Pre-incubation with $\mathrm{SAgA}$ Ins renders IBCs refractory to re-stimulation through the BCR by anti-IgM [B76] but not to stimulation with the calcium ionophore, ionomycin (io) (C.). This induced tolerance is independent of the surface expression of BCR (gating in B.). Dashed calcium traces represent $\mathrm{AgA}_{\text {Ins }}$ treated (C.) or untreated (A.) cells stimulated with a 5-fold excess [25 ug] of anti-IgM . Data are representative of at least 3 independent experiments. 


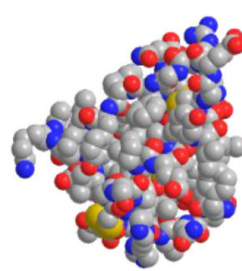

Human Insulin

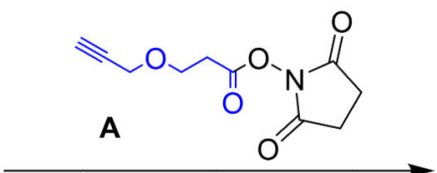

1) TEA, DMSO, $30 \mathrm{~min}$ 2) $A(T H F), 1 \mathrm{~h}$

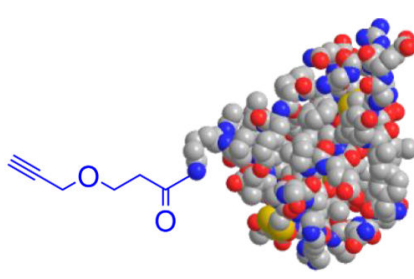

Insulin-Alkyne (Ins-Alk)
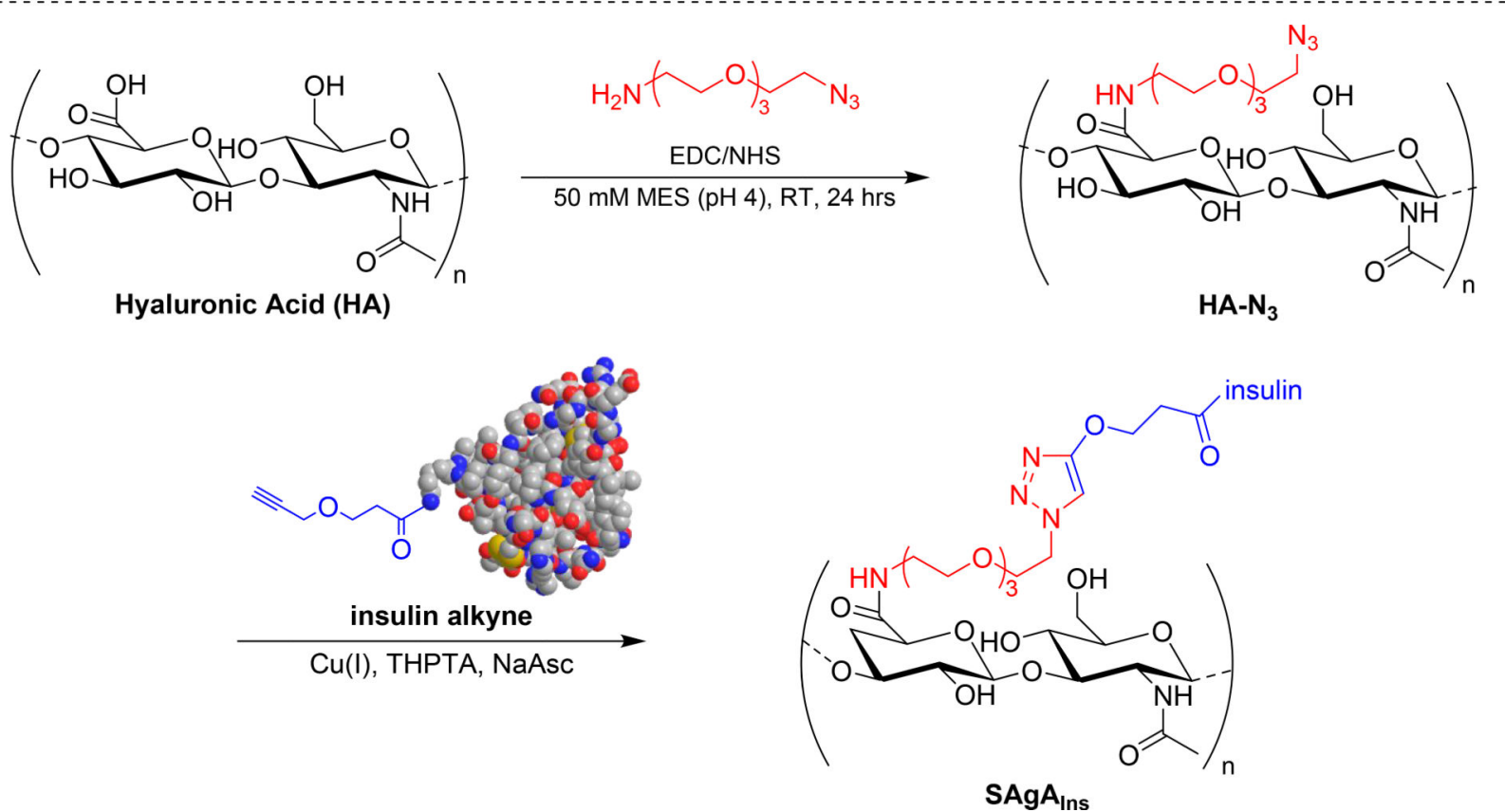

Scheme 1.

(A): Synthesis of modified human insulin alkyne; (B) General synthesis of SAgA Ins 
Table 1.

Insulin molar conjugation, as determined by RP- HPLC ${ }^{a}$. Dynamic light scattering (DLS) of SAgAs and components.

\begin{tabular}{|c|c|c|c|c|}
\hline \multirow{2}{*}{ Sample } & \multirow{2}{*}{ Approx. MW (kDa) } & \multirow{2}{*}{ Insulins per Polymer ${ }^{c}$} & \multicolumn{2}{|c|}{$\mathrm{DLS}^{d}$} \\
\hline & & & Radius (nm) & \%Polydispersity \\
\hline Insulin & 5.81 & 0 & $2.09 \pm 0.02$ & 8.00 \\
\hline HA- $\mathrm{N}_{3}$ & 24.50 & 0 & $6.5 \pm 0.03$ & 24.50 \\
\hline${ }_{\text {In }} \mathbf{S A g A}_{\text {Ins }}$ & 36.34 & 2 & --------- & ---------- \\
\hline${ }^{{ }_{m} \mathbf{S A g} A_{\text {Ins }}}+$ & 48.17 & 4 & $14.07 \pm 0.63$ & 26.55 \\
\hline${ }_{\text {hv }} \mathbf{S A g A} \mathbf{A}_{\text {Ins }}$ & 77.76 & 9 & $14.07 \pm 0.15$ & 24.52 \\
\hline
\end{tabular}

${ }^{a}$ Results are an average of triplicate injections from a single batch preparation.

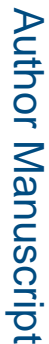

${ }^{b}$ Calculated from RP-HPLC data. MW, molecular weight.

$c_{\text {Insulin per HA, hyaluronic acid }}$

${ }^{d}$ DLS data were collected in triplicate 